\title{
WestVirginiaUniversity
}

THE RESEARCH REPOSITORY @ WVU

West Virginia Agricultural and Forestry Experiment

Davis College of Agriculture, Natural Resources

Station Bulletins

And Design

$1-1-1958$

\section{Internal Bark Necrosis of Apple Resulting from Manganese Toxicity}

Anthony Berg

Genevieve Berg Clulo

C. R. Orton

Follow this and additional works at: https://researchrepository.wvu.edu/ wv_agricultural_and_forestry_experiment_station_bulletins

\section{Digital Commons Citation}

Berg, Anthony; Clulo, Genevieve Berg; and Orton, C. R., "Internal Bark Necrosis of Apple Resulting from Manganese Toxicity" (1958). West Virginia Agricultural and Forestry Experiment Station Bulletins. 414T.

https://researchrepository.wvu.edu/wv_agricultural_and_forestry_experiment_station_bulletins/643

This Bulletin is brought to you for free and open access by the Davis College of Agriculture, Natural Resources And Design at The Research Repository @ WVU. It has been accepted for inclusion in West Virginia Agricultural and Forestry Experiment Station Bulletins by an authorized administrator of

The Research Repository @ WVU. For more information, please contact ian.harmon@mail.wvu.edu. 
June 1958

Internal Bark Necrosis

of Apple Resulting from

Uanganese Toxicity 


\title{
THE AUTHORS
}

Anthony Berg, Genevieve Clulo (Berg), and C. R. Orton were respectively, Plant Pathologist, Associate Plant Pathologist, and Plant Pathologist and Director, West Virginia University Agricultural Experiment Station. All are now deceased.

\author{
WLST VIRGINIA UNIVERSTI) \\ Agricilltukal Experiment Station \\ College of Agriculture, Forestry, and Home Economics \\ 1. H. Vanlandingham, Acting Diregtor \\ MORGANTOWN
}




\section{Internal Bark Necrosis of Apple Resulting from Manganese Toxicity}

Anthony Berg, Genevieve Clulo [Berg] and C. R. Orton

\section{Purpose of Bulletin}

THE purpose of this bulletin is to make available in one place the results of studies on the relationship of Internal Bark Necrosis to manganese toxicity and to present the detailed data from which conclusions reported here were reached. The methods used, and the materials employed in carrying out the different studies, together with the discussion of the results of these studies in relation to published information are given.

\section{Internal Bark Necrosis in Relation to Other Apple Bark Diseases}

Much interest and considerable confusion has existed among horticulturists and orchard owners who have been laced with a variety of somewhat similar apple bark diseases. The first workers to describe onc of these diseases in detail were Heritt and Truax (17) who applied the name Apple Measles to a pimpled or bistered and often reddish discoloration of young bark. Such symptoms may later develop into a roughening of the older bark and sometimes they precede canker development. To this whole syndrome of frecpuently diverse successive ymptoms, the tem Apple Mcasles has been applied.

Berg, in 1934, made a thorough study of the meatses complex as it xcurs in West Virginia and he delimited three distinct diseases within the "measles" complex (2). One was caused by the fungus Helminthosporium bopulosum. This disease Berg named Black Pox. He gave the name Internal Bark Necrosis to another cliscase which was characteried by he presence of groups of dead cells within the living bark. This discanc vat associated particularly with the variety Irelicious. The third type It bank condition, found most often on the Yonk vallicty in West V'ininia, most closely approximates the original description of apple llcasles.

Internal Bark Necrosis was comsidered to be caused by boron deiciency by Young and Winter (31) and by Hiddebrand (18). In 194 (6.

'The manuscript was edited by R. P'. True, Plant Pathologist, Department of plant 'athology, Bacteriology, and Entontology, West Virginia luiversily dgricultural Experiifnt stalion. 
berg and chulo, using sand cultures in the greenhouse, showed that the disease resulted from manganese toxicity (4, 5). Berg and Clulo (9) were unable to confirm the relationship of Internal Bark Necrosis to boron deficiency in West Virginia. Later, Clulo and Berg (9) published the results of investigations in which they used boron in sand culture studies. These showed that Internal Bark Necrosis was not related to the concentration of boron.

Meanwhile, Dunegan and Isely (II) showed what they consider to be the original discase described by Hewitt and Truax to be caused by the deposition of the winter eggs of the white apple leaf hopper, Typhlocya pomaria McAtee. Crawford (10), in a study of Apple Measles in New Mexico, produced the symptoms on Jonathan apple in high concentrations of soluble salts, largely sodium chloride and sodium nitrate, which are commonly present in the alkahine soils of that state. Othen similar but still undelimited symptomatic diseases have been reported $(17,22,23)$, and in England a disease of apparently similar nature ha: been ascribed to the bactcrium Pseudomonas papulans by Lacy an Dowson (20).

\section{Economic Importance}

This bulletin deals with Internal Bark Necrosis, a discase whicl appeared in West Virginia simultaneously with the introduction of th apple variety Delicious. The disease is principally confined to this variet and its sports, though it occurs occasionally on other varieties. Th popularity of Delicious has led to its extensive planting throughout th nation, and Internal bark Necrosis has been found wherever this variet has been planted on highly acid manganiferous soils. Although most c our commercial varietics are somewhat more resistant to manganes toxicity than Delicions, the disease has been reported occasionally o Golden Delicions, Grimes, Jonathan, McIntosh, Rome, Northwester Greening, Stayman, York, and King David. Rhodes (22), in a study c the susceptibility of Missouri apple varieties to Apple Measles, foun only the latter two severely affected. Concentrations of manganes which affected Delicious and Blaxstayman failed, in greenhouse tes in West Virginia, to induce symptoms in the other varieties listed her Diseased trces are unthrifty and branches or sometimes the whole tre may die. Losses in individual instances have been so considerable thi young plantings of Delicious have been pulled and replaced by othe varieties.

\section{Symptoms}

Characteristic symptoms of Internal Bark Necrosis appear on tl bark of stems but have not been found on roots. The lower portion 
of discaned stems, the trunks and lower branches, and the leaves borne on these branches are, under orchard conditions, most likely to be severely affected. Bark symptoms may develop more severely on only one side of a diseased tree, or all sides may be affected equally. The leares of cliseased trees or aftected branches may be small, and show a yellow discoloration sometimes as intervenal chlorosis and sometimes as large or small yellow areas. These yellow areas may appear in combination with green portions of the leaf, which sometimes have a distinctly purplish tint. Affected leaves are likely to be shed prematurely.

Thrce types of stem lesions have been observed-the pimply, the ocdematous, and the mimute superficial lesions. Of these, pimply lesions are the most common. They are found in association with the other two types when they appear.

Pimply lesions develop from small necrotic areas which originate deep in the cortex and pericycle. At first, such tesions may be surrounded by apparently nomal healthy tissues (Figure 1, a). Later, these groups of necrotic cells may beconse encysted within the bark by the development of an enclosing layer of suberized cells (Figure 1, b). The first externally visible indications of this condition are raised points that appear on the epidermal surface (Figure 2, a). These localized swellings are due to the hyperplasia that occurs in living tissues bordering the groups of necrotic cells. These elevations of the epidermis are usually larger, and present more variation in size and shape than those that characterize the "measles" disease of Hewitt and Truax. In severeIy diseased trees necrotic areas may develop in any parenchymatous tissue, even in wood parenchyma (8).

Where the pockets of dead tissue in the bark are comparatively mall and isolated, the external elevations develop into more or less semispherical papules. However, in cases where they are larger, ireguar in shape, or closely aggregated, the bark becomes unevenly elevated nto unclulating ridges, the contour of which may gradually change, me the upheaval of the bark often continues for more than one year Figure 2, b). The peridem covering the papules of ridged arcas may ('main smooth and apparenty nomal throughout the first seasom, or t may assume a redkish, or dark-brown pigmentation. In other cascs, earl, slightly sumken patches appear on the smmmit of some of the idged areas with the periderm tuming light brown and beginning to heck and scale by the end of the first seatson.

In the course of time the number of such dead areas increases. tre radial development of the bark is retarded, and numerous short, regular cracks appear. The checking of the bark and scaling of the eriderm may continue for several years until the bark on severely flected limbs and branches assumes a chatrateristic sealy, cracked and 


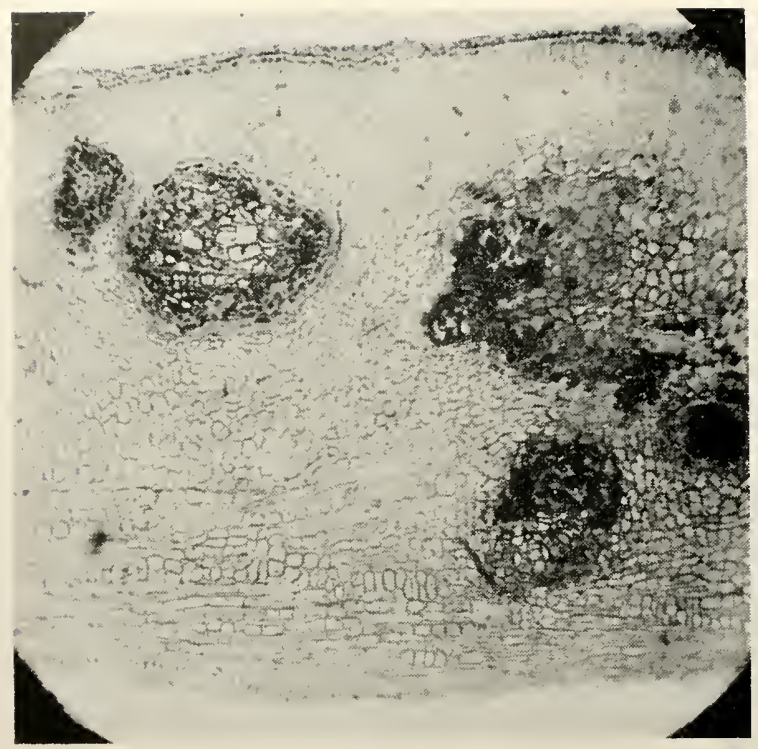

a

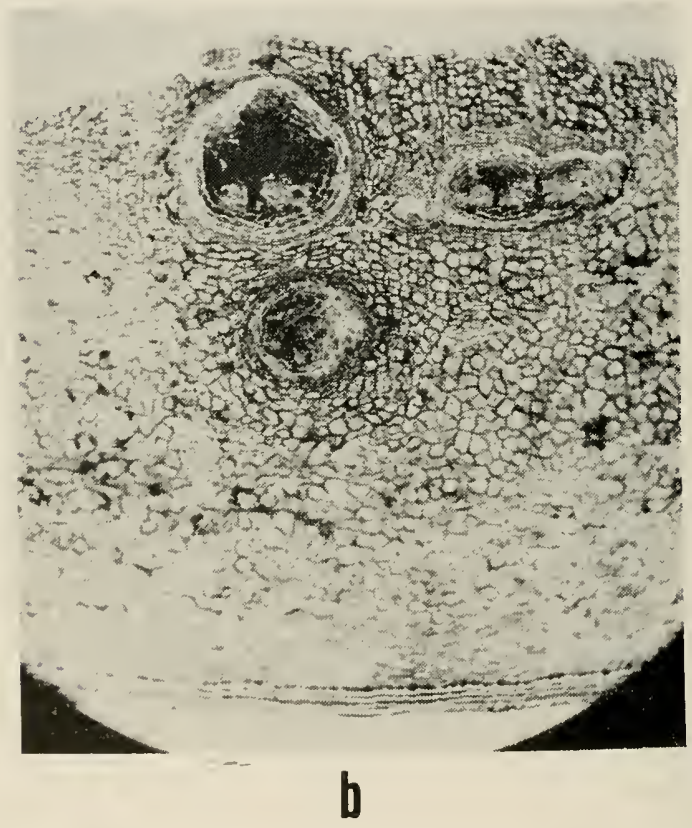

FIGURE 1. Sections through the cortex and phloem of apple twigs affected with Internal Bark Necrosis. (a) Necrotic areas in the cortex not yet walled off from adjacent tissues. (b) Necrotic areas involving the inner cortex and outer phloem which have been surrounded and walled off from the living tissue by layers of pathological cork cells. 


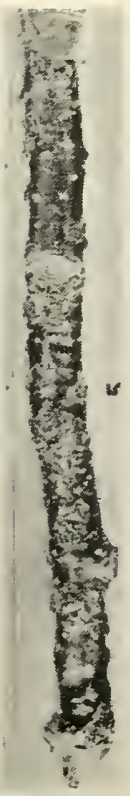

b

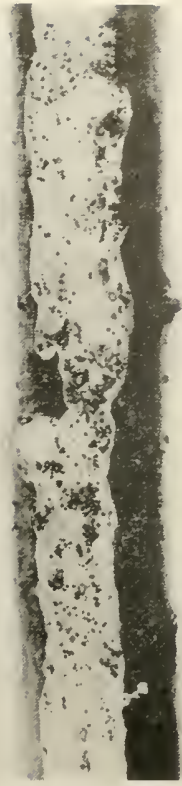

C

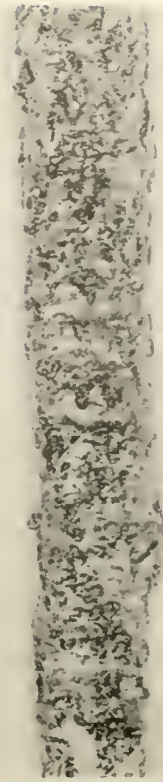

d

a

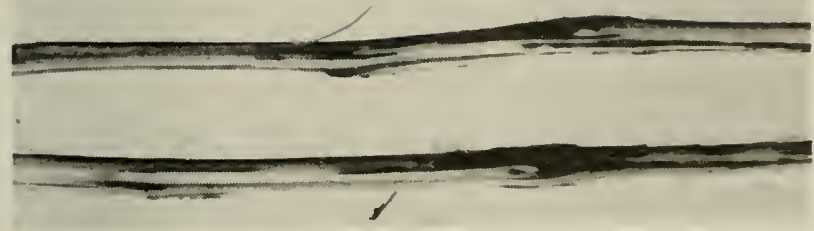

e

FIGURE 2. Symptoms of Internal Bark Necrosis. (a) Early symptoms, raised points that appear on the epidermal surface of affected twigs. (b) Larger, irregularly-shaped papules and uneven undulating ridges that may develop where epidermal elevations continue to swell or are closely aggregated. (c) Irregularly-circular areas of dead cells are visible within the cortex and liv. ing phloem when exposed by slicing off the outer surface layers of affected iwigs and branches. (d) Roughened bark may become irregularly-cracked and scaly if the condition persists for several years. (e) Short dark streaks that nay be visible at the cambium layer when affected bark is removed from disased twigs.

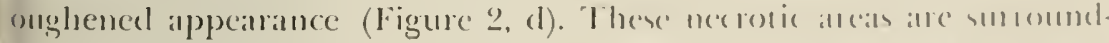

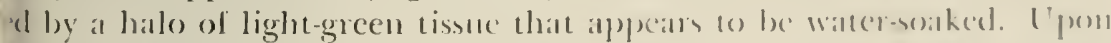

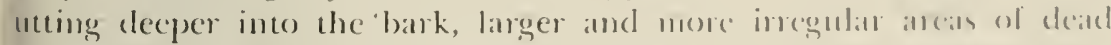
ells are noted (Figure 2, c). Somctimes namow blath streathe ome contineter or more in length, of discolored pericyclic fibers enged her with onthes ells aljacent to them will be diselosed. Such strands ane oflen completely 
surrounded by a phellogen (Figure l, b). In some instances the internal necrotic areas extend imward to the cambium, and corresponding darkened streaks may appear in the wood internal to necrotic bark streaks or lesions (Figure 2, e).

Oedematous and also minute superficial lesions can be distinguished from the pimple-type lesions described above, but some pimply lesions are found wherever lesions of these other types are present; and all are considered symptoms of Internal Bark Necrosis.

Oedematous lesions most commonly occur at the base of the tree or in isolated areas of limited extent higher on the main stem. Only rarely are they found on the bark of stems less than one year old. They generally appear in greenhouse-grown trees in early August of the year following their planting into toxic soil. The bark of the oedematous lesions swells conspicuously and has a water-soaked appearance. The outer periderm over these swellings splits parallel to the axis of the stem and becomes loose over the swollen area so that it appears as a series of tan papery sheets covering the unruptured portions of the swelling. Directly below the layered periderm the cells are usually bright green, large, and have a mealy texture. Within two weeks after oedematous lesions have split open, the underlying tissues turn brown and collapse. The wood under oedematous lesions is frequently discolored. Orange or dark-brown patches, or occasionally black streaks, may develop there.

Minute superficial lesions are caused by the localized stimulation of the normal periderm to increased activity. They are clearly visible under the hand lens as darkened points, are perceptible to the touch, and are confined to the terminal portion of the current season's matured growth.

\section{Earlier Studies on the Nature of Internal Bark Necrosis}

Some early investigators concluded that Internal Bark Necrosis, as described by Berg (2), was due to boron deficiency (18, 31). Recently, Shannon (26) concluded from sand-culture studies that manganesc toxicity was more active than boron deficiency or toxicity of iron or aluminum in inducing symptoms that he considered those of Internal Bark Necrosis. However, the symptoms Shannon obtained when boron was delicient were typical of boron deficiency rather than of Internal liark Necrosis as described here. Berg and Clulo (3) showed in botl licld and greenhouse experiments that Internal Bark Necrosis was not related to boron concentration. In the course of more extensive studic: Chulo and Berg (9) noted during their analysis of boron in the leave: and bark that the ash from diseased trees was always dark in comparisor with the ash from corresponding tissues of healthy trees. They alsc noted that when the inner bark of diseased trees was exposed to air 
oil cloth cut to fit the trees. A mutrient solution," made up carh weck, was changed twice daily following a llushing out of the sand with double-chistilled water. The pH of the culture solution after passing through the sand was 4.6. Manganese sulfate was added to the basic untricnt solution in quantities which supplied from 0.5 to 128 parts per million (ppon of $\mathrm{Mn}^{++}$). The results, given in Table 1 , show clearly

Table I. EFflat of Inckliasing: Concentration of Manganese dined as MnSO, To the Nutrlint Solition on the Manganese Content and Simprom Expression in Delicious Aplete Grown in Sand Culture1945.*

\begin{tabular}{|c|c|c|c|}
\hline \multirow{2}{*}{$\begin{array}{c}\text { MANGANESE ADDEN } \\
\text { TO BASIC NUTRIENT } \\
\text { (ppm) }\end{array}$} & \multicolumn{2}{|c|}{ Average Manganese Content of Tissues } & \multirow{2}{*}{$\begin{array}{c}\text { SYMPTOM } \\
\text { EXPRESSION ** }\end{array}$} \\
\hline & $\begin{array}{c}1945 \text { LEAVES } \\
\text { (ppM) }\end{array}$ & $\begin{array}{c}1945 \text { BARK } \dagger \\
(\mathrm{ppm})\end{array}$ & \\
\hline 0.5 & 54 & 42 & NONE \\
\hline 1.0 & 66 & 64 & NONE \\
\hline 2.0 & 106 & 77 & NONE \\
\hline 4.0 & 155 & 107 & NONE \\
\hline 8.0 & 193 & 107 & NONE \\
\hline 16.0 & 291 & 209 & NONE \\
\hline 32.0 & 532 & 330 & SLIGHT \\
\hline 64.0 & 832 & 543 & SEVERE \\
\hline 128.0 & 1034 & 764 & SEVERE \\
\hline
\end{tabular}

* Results hased on average for two trees receiving each treatment.

i Indicates bark removed from stem elongations produced in 1945 .

** Categories of symptom severity used were: None, Slight, Moderate and Severe.

that there was a progessive intake of manganese reflected in increasing manganese concentrations in both bark and leaves, positively correlated with the dosage of manganese sulfate. By the end of the first growing season only one tree treated with 32 ppun of manganese (in addition to the ().5 ppm fumished in the basic nutrient) developed the disease on the current season's bark. With the 64- and 128-ppm treatments, Internal Bark Necrosis developed with severe symptoms shown on the bark of both the current and the previous season's growth. A similar experiment carried out in 1947, using three manganese concentrations on treatment groups of ten trees each, gave similar results. These are shown in Table 2.

(2) The addition of rarious quantities of $\mathrm{MnSO}_{4}$ and of iron tartrate alone and together-io soil taken from a healthy orchard (or to crocks of washed sand as in Experiment 1) in which apple whips were

" Basic nutrient solution : $\mathrm{KH}_{2} \mathrm{PO}_{4}, 0.0108 \mathrm{M}$. (Molar concentration); $\mathrm{CaNO}_{3}, 0.0780 \mathrm{M}$. $\mathrm{MnSO}_{4}, 0.0020 \mathrm{M}$; $\left(\mathrm{NH}_{4}\right)_{2} \mathrm{SO}_{4}, 0.0007 \mathrm{M}$ : : boron as boric acid, 2 pnm (parts per million) iron, as iron tartrate 6 ppm; zinc, as $\mathrm{ZnSo}_{4}, 0.2$ ppm; copper as $\mathrm{CuSO}_{4}, 0.1$ ppm; anc manganese, as $\mathrm{MnSO}_{4}, 0.5$ ppm per liter of solution. 


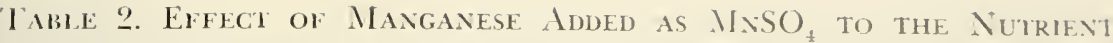
SOlution on Manganese Content ANd Symptoli Expression IN

Delicious Apple Gromin in Sand Gulture-1947.*

\begin{tabular}{|c|c|c|c|c|c|}
\hline \multirow[b]{2}{*}{$\begin{array}{c}\text { MANGANESE ADDED } \\
\text { TO BASIC NUTRIENT } \\
(\mathrm{ppm})\end{array}$} & \multicolumn{4}{|c|}{ Average MiANGaxese CoNtext of TISstes } & \multirow[b]{2}{*}{$\begin{array}{l}\text { SYMPTOM } \\
\text { EXPRESSION }\end{array}$} \\
\hline & $\begin{array}{c}\text { TOP } \\
\text { LEAVES } \\
\text { (ppm) }\end{array}$ & $\begin{array}{l}\text { BASAL } \\
\text { LEAVES } \\
(\mathrm{ppm})\end{array}$ & $\begin{array}{r}1947 \\
\text { BARK } \\
(\text { ppm) }\end{array}$ & $\begin{array}{c}1946 \\
\text { BARK } \\
(\mathrm{ppm})\end{array}$ & \\
\hline 0.5 & 116 & 183 & 71 & 94 & NONE \\
\hline 8.0 & 317 & 264 & 180 & 221 & NONE \\
\hline 64.0 & 1290 & 500 & 657 & 862 & SEVERE \\
\hline
\end{tabular}

* Results based on average for 10 trees receiving each treatment.

grown in the greenhouse showed that incidence and serierity of symptoms increased with the addition of manganese, either alone or with iron, but that the addition of iron alone failed to induce Internal Bark Necrosis.

While it was proved that an excessive dosage of manganese will produce Internal Bark Necrosis, it had been observed also that the disease was often associated with soils high in iron compounds. Since minganese and iron are generally associated in our soils it seemed necessary to test both elements in relationship to this clisease.

Apple whips headed to 10 inches were planted in glazed crocks in the greenhouse on April 18, 1947 in soil taken from an orchard near Morgantown where the disease does not occur naturally." On the same date iron tartrate was added at rates which supplied 96 to 768 ppm iron to onc treatment block; magnanese sulfate was atcled at the same rates to a third treatment block; and manganese sulfate and iron tartrate were added in inverse ratio to trees in a fouth block. The trees were held over in this same soil to the second year at the end of which perion analyses were made with results shown in Table 3.

The data show that where iron tartrate alone was supplied, Intemal Bark Necrosis lailed to develop. Where manganese sulfate was added in sufficiently high concentration, either alone or in various combinations with iron tartrate, the disease was produced.

Aclelitional studies of the effect of iron were carried out by the ate dition of iron, as tartrate, to a balanced nutrient solution utpplied (o) Delicious apple growing in sand culture als in Experintent $\mathrm{No}$. 1.

Thirty-two Red Delicious apple whipe were cut back to lo inches and planted in crocks in acid-washed sand. The trees were supplied with the basic mutrient solution for thee weeks after planting. Throughour

3 The soil was taken from the Hustrin property near Morgantown where Rod Dellelous apples had grown for 20 years without developlug symptoms of luternul Hark Nerrosls. 


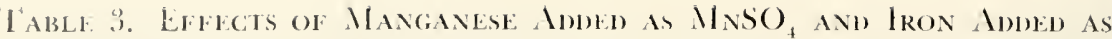
Iron Tartrate Upon Manganese Content and SyMpton Expression by 1) eliciols Apple When Apllied Both Alone and Together in Various Concentrations and Combinations to Potting Soll Obtained from A Healthy Orchard.*

\begin{tabular}{|c|c|c|c|c|c|c|c|}
\hline \multirow{2}{*}{\multicolumn{2}{|c|}{$\begin{array}{c}\text { Treatments } \\
\text { Concentrations }\end{array}$}} & \multirow{2}{*}{\multicolumn{2}{|c|}{$\begin{array}{c}\text { HIRST SEASON RESULTS } \\
\text { MANGANESE } \\
\text { CONTENT }\end{array}$}} & \multirow{3}{*}{$\begin{array}{c}\text { SYMPTUM } \\
\text { ExPRESSION } \\
\text { ON CURRENT } \\
\text { SEAsON's } \\
\text { GHOWTH }\end{array}$} & \multicolumn{2}{|c|}{ Second Season Results } & \multirow{3}{*}{$\begin{array}{c}\text { SOIL } \\
\text { pH } \\
\text { AT END } \\
\text { OF } \\
\text { 2ND } \\
\text { SEASON }\end{array}$} \\
\hline & & & & & \multirow{2}{*}{$\begin{array}{c}\text { MANGANESE } \\
\text { CONTENT } \\
\text { LEAVES } \\
\text { (ppm) }\end{array}$} & \multirow{2}{*}{\begin{tabular}{|c|} 
SYMPTOM \\
EXPRESSION \\
ON CURRENT \\
SEA SON'S \\
GROWTH
\end{tabular}} & \\
\hline $\begin{array}{l}\text { IRON } \\
\text { (ppm) }\end{array}$ & $\begin{array}{c}\text { MANGANESE } \\
\text { (ppm) }\end{array}$ & $\begin{array}{l}\text { LEAVES } \\
(\mathrm{ppm})\end{array}$ & $\begin{array}{l}\text { BARK } \\
(\mathrm{ppm})\end{array}$ & & & & \\
\hline 96 & NONE & 138 & 64 & NONE & - & NONE & 4.92 \\
\hline 192 & NONE & 176 & 138 & NONE & 393 & NONE & 4.92 \\
\hline 384 & NONE & 158 & 108 & NONE & 384 & NONE & 4.86 \\
\hline 768 & NONE & 132 & 135 & NONE & 226 & NONE & 1.76 \\
\hline NONE & 96 & 164 & 155 & NONE & 372 & NONE & 4.83 \\
\hline NONE & 192 & 1026 & 328 & SLIGHT & 750 & SLIGHT & 4.86 \\
\hline NONE & 384 & 337 & 262 & SLIGHT & 761 & MODERATE & 4.88 \\
\hline NONE & 768 & $12+2$ & 440 & SLIGHT & 1090 & SEVERE & 4.90 \\
\hline 96 & 96 & 396 & 190 & NONE & 343 & NONE & 4.76 \\
\hline 192 & 192 & 615 & 314 & SLIGHT & 615 & NONE & 4.73 \\
\hline 384 & 384 & 908 & 346 & SEVERE & 902 & MODERATE & 4.76 \\
\hline 768 & 768 & 1172 & 390 & SEVERE & 1277 & SEVERE & 4.66 \\
\hline 96 & 768 & 762 & 322 & SEVERE & 785 & SLIGHT & 4.83 \\
\hline 192 & 384 & 1348 & 272 & SEVERE & 996 & SLIGHT & 4.88 \\
\hline 384 & 192 & 308 & 240 & SLIGHT & 375 & NONE & 4.92 \\
\hline 768 & 96 & 565 & 204 & SLIGHT & 545 & NONE & 4.84 \\
\hline
\end{tabular}

* Figures are based upon the individual responses of 16 trees, each of which recoived one of the treatments listed in the left-hand column of the table. The treatments listed were added to 15 pounds of air-dried potting soil.

the experiment, four control trees received this nutrient solution alone. The remaining trees were divided into groups of four per treatment and iron was supplied in the form of iron tartrate, the concentration of which was increased by cloubling in geometric progression from 12 to $768 \mathrm{ppm}$. All trees were supplied with $0.5 \mathrm{ppm}$ manganese in the fom of manganese sulfate in the basic nutrient. The four trees given $768 \mathrm{ppm}$ Fe died during the first weck of treatment. The control trees as well as the remaining treated trees grew well but none became diseased. These results lurther substantiate the conclusion that iron is not directly concerned with the development of Internal Bark Necrosis.

(3) Treatments that acidified manganiferons soils, lowering thein fHe camsed an increase in the incidence and sezerity of Intermal Bark Necrosis in I elicions apple growen in treated solils in the greenhonse. such trentments included the addition of $\left(\mathrm{NH}_{4}\right)_{2} \mathrm{SO}_{4}$, sulfur, and of $\mathrm{H}_{2} \mathrm{SO}_{+}$to naturally manganiferous soil. ${ }^{4}$

t The soil was obtained from the Huxham orchard near liuntington where Internal Bark Necrosis has frequently appeared and sometimes caused severe injury. 
(a) Ammonimm sulfote was applicel to Delicious apple whips cut back to 11 inches planted May 23, 19.46 in a uniform manganiferous soil contained in glazed crocks with bottom drainge. Ammonium sulfatc at the rate of $15 \mathrm{gm}$ per 15 lbs of air-bried soil was adcled to in trees on July 9. Thinty trees were reserved as untreated checks. The urees were titken down September 6th and analyses made of the leaves and bark with the results shown in Table 4.

It is to be noted that all trees receiving ammonimm sulfate treatmont became diseased, while 5.3 .9 per cent of the checks romaned healthy. While the soil of both treated and check pots had a milorm pH when trees were planted, the addition of the ammonimu sullate increased the aciclity by $(0.90 \mathrm{pH}$ unit. The manganese content of the bark appears to be a more reliable index of the occurrence and severity of manganese toxicity than the quantity of manganese fomnd in the leaves.

(b) Sulfur was applied in thee different concentrations, in each casc throughly mixed with a highly manganiferous orchard soil. Trees were planted in these soils in the greenhouse in the spring of 1946. Trees which showed no symptoms of Internal Bark Necrosis at the cnd of that season were carried over winter in cold storage and gromm for a scond scason in the same soil. The results are shown in Table 5 . It is clear that the addition of sulfur caused an increase in the incidence and severity of Internal Bark Necrosis and in the nuanganese content of the trees in treated soils. As expected, the soil pH was found to decrease ats a result

\section{TABLE 4. EFFECT OF $\left(\mathrm{NH}_{4}\right)_{2} \mathrm{SO}_{4}$ AIDDED TO A NATTRALI.Y MAGANIFFROUS}

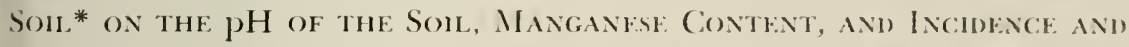

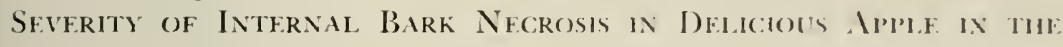

\section{Greenhouse.}

\begin{tabular}{|c|c|c|c|c|c|}
\hline \multirow[b]{2}{*}{ TREATMFNT } & \multirow[b]{2}{*}{ SYMPTOMS } & \multirow{2}{*}{$\begin{array}{l}\text { Number } \\
\text { OF } \\
\text { AfFectel } \\
\text { TreEs }\end{array}$} & \multicolumn{2}{|c|}{$\begin{array}{l}\text { AVERAGF } \\
\text { MANGANESE CONTENT } \dagger\end{array}$} & \multirow{2}{*}{ 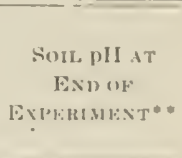 } \\
\hline & & & $\begin{array}{l}\text { 1947 } \\
\text { LEAVES } \\
(\text { PPM })\end{array}$ & $\begin{array}{l}1947 \\
\text { ИARK } \\
\text { (ppm) }\end{array}$ & \\
\hline $\begin{array}{l}\mathrm{NH}_{4} \mathrm{SO}_{4}-15 \mathrm{gm} \\
\text { per } 15 \text { lbs. of soil }\end{array}$ & $\begin{array}{c}\text { NONE } \\
\text { SLIGHT } \\
\text { MODERATE } \\
\text { SEVERE }\end{array}$ & $\begin{array}{l}0 \\
5 \\
3 \\
2\end{array}$ & $\begin{array}{l}\overline{1305} \\
1452 \\
1398\end{array}$ & $\begin{array}{l}- \\
571 \\
638 \\
7 i 55\end{array}$ & $\begin{array}{l}4.61 \\
1.58 \\
4.57\end{array}$ \\
\hline Controls & $\begin{array}{c}\text { NONE } \\
\text { SIJGHT } \\
\text { MODERATE }\end{array}$ & $\begin{array}{r}16 \\
12 \\
2\end{array}$ & $\begin{array}{l}0.93 \\
11501 \\
16: 20\end{array}$ & $\begin{array}{l}107 \\
+711 \\
1328\end{array}$ & $\begin{array}{l}1.85 \\
1.87 \\
1.41\end{array}$ \\
\hline
\end{tabular}

* The soll was obtained from the Huxham orchard near lluntington whor Internal Barh Vecrosis has frequently appeared and sometimes caused severe injury.

t Figures given represent manganese content at the end of the expermont bxperimement trees were oblained from a slngle nursery and consisteully had low and ruber unlform content of manganese when tested.

* The soll pli at planting lime was 5.1. 


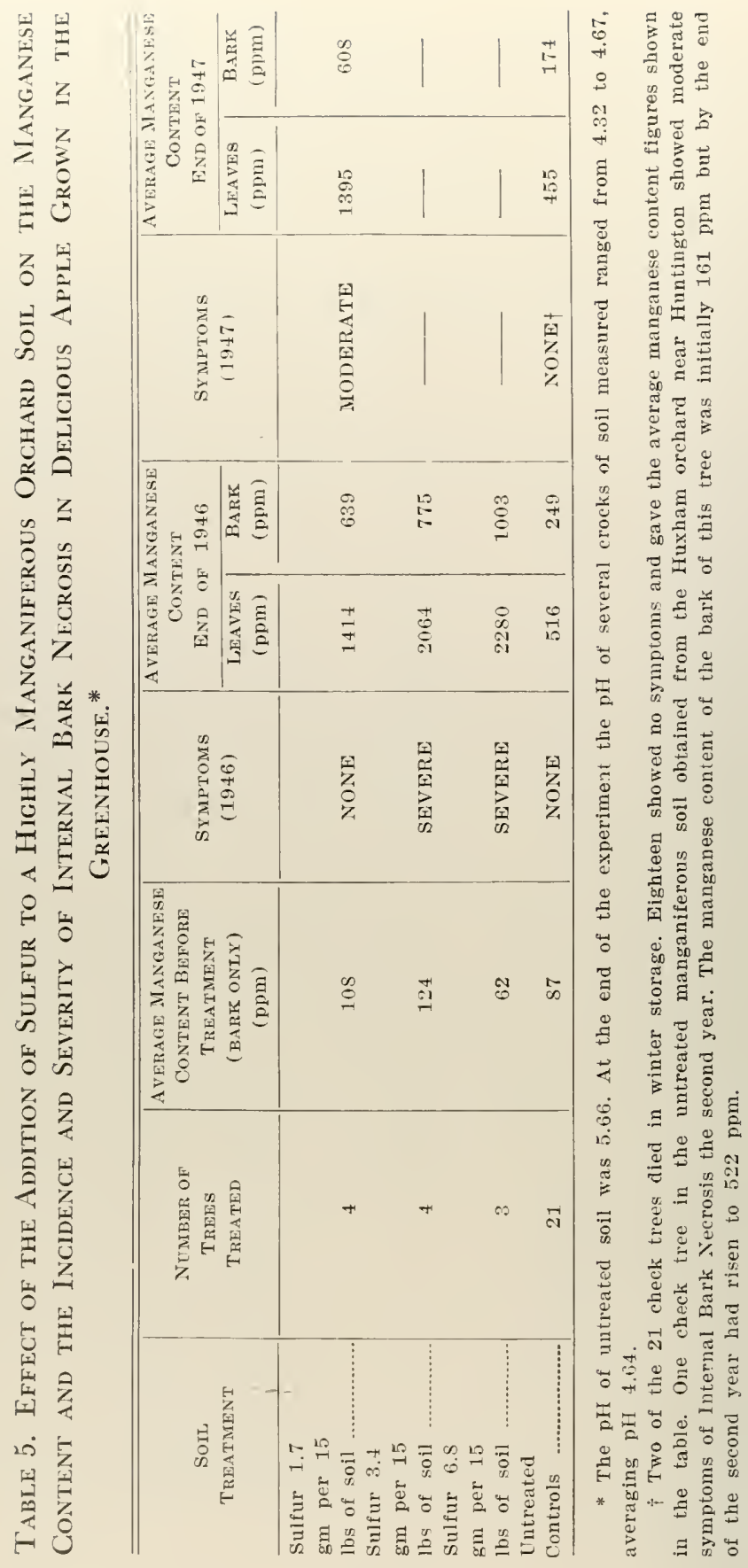


of the addition of sulfur. Manganese is known to be made more readil avaibble in soils of high acidity (16). Fujimoto and Sheman (1.1) found that the addition of sulfur to soil increased the absorption of mangancse from it by plants.

(c) Sulfuric acid, the third soil-acidifying agent used, was likewise added in three different extreme dilutions to glazed crocks of highly manganiferous soil on April 19, 1946. Whips of Delicious apple were planted in these crocks of treated soil May 4.

There was a progressive increase in the manganese content of leaves and bark correlated with the dosage of sulfuric acid applied (Table 6), but little significant increase in the severity of symptoms beyond that attained by the addition of the smallest quantity of sulfuric acid (2.8 $\mathrm{gm} . / 15$ 1b. of soil).

(-1) Treatmonts that neutralized highly manganiferous orchard soil. Iowering its acidity as indicated by increasing pH measurements, caused incidence and severity of Intermal Bark Necrosis to decrease. Surh treatments included the addition of $\mathrm{Ca}(\mathrm{OH})_{2}, \mathrm{CaCO}_{3}, \mathrm{MgCO}, \mathrm{MgO}$, and $\mathrm{NaCO}_{3}$ to highly manganiferons orchard soils.

The neutralizing compounds were added at planting time to $15 \mathrm{lbs}$. of air-dried soil which was placed in each of several glazed crocks with bottom drainage into which Delicious apple whips were planted. The experiments extended over a period of three years with the results shown in Table 7.

All of these neutralizing compounds decreased the soil acidity and prevented the development of manganese toxicity. Fujimoto and Sherman

Table 6. Effect of the Addition of Varying Quantities of Sul.ruric Acid to a Highly Manganiferous Orchard Soll on the Manganesf Content and the Incidence and Severity of Internal Bark Necrosis in Delicious Apple Grown in the Greenhouse.

\begin{tabular}{|c|c|c|c|c|c|c|c|c|}
\hline \multirow{3}{*}{ SHI. TEATMENT } & \multirow{3}{*}{$\begin{array}{c}\text { NTMBFR } \\
\text { of } \\
\text { TrFEs } \\
\text { TREATFD }\end{array}$} & \multirow{3}{*}{\begin{tabular}{|} 
AVERAGE \\
MANGANESE \\
CONTENT \\
OF BARK \\
BFFORF: \\
TREATMENT \\
(1)MII)
\end{tabular}} & \multirow{3}{*}{$\begin{array}{c}\text { AVERAGE } \\
\text { SoI pH* } \\
\text { AFTHR } \\
\text { TRFAT- } \\
\text { MENT } \\
\text { (pH) }\end{array}$} & \multirow{3}{*}{$\begin{array}{l}\text { SYMP'МM: } \\
(19+6)\end{array}$} & \multicolumn{4}{|c|}{ 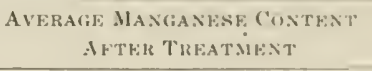 } \\
\hline & & & & & ISAVES & & & $\begin{array}{l}\text { R(ख)T } \\
\text { M.1Rli }\end{array}$ \\
\hline & & & & & $\begin{array}{l}(194+i) \\
(p)+m)\end{array}$ & $\mid \begin{array}{l}(1)+(1 i) \\
(\text { p)มn })\end{array}$ & $\left|\begin{array}{l}(1,445) \\
(123,113)\end{array}\right|$ & (P) \\
\hline $\begin{array}{l}\mathrm{I}_{2} \mathrm{SO}_{4}, 2.8 \mathrm{gm} \\
\text { er } 15 \mathrm{lbs} \text { of soil } \\
\mathrm{SO}_{4}, 5.6 \mathrm{gm}\end{array}$ & 4 & fit & $4.9 \pi$ & MOINERATE & $1+1 i s$ & 75.5 & $7 \times 5$ & s:::2 \\
\hline $\begin{array}{l}{ }_{2} \mathrm{SO}_{4}, 11.2 \mathrm{gm}\end{array}$ & 4 & 59 & $4.5 n$ & SFVERL: & $2 x 72$ & 957 & 1253 & ass \\
\hline $\begin{array}{l}\text { ntreated } \\
\text { ntres of soil }\end{array}$ & 4 & 63 & 4.47 & SEVERE & 5200 & $182::$ & $: \because 13 ! 11$ & 1570 \\
\hline Checks .......... & 21 & 87 & & NONE & 516 & 219 & 181 & si \\
\hline
\end{tabular}

* Sosil pll was initially 5.fif. 


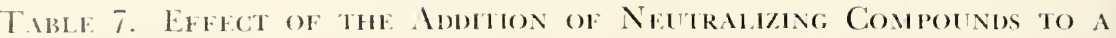
Highl Mangandlerous Orchard Soll on the Manganese Content and

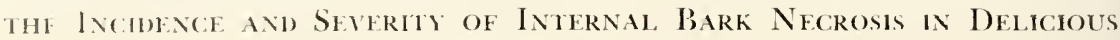
Apple Grown in the Greenhouse.

\begin{tabular}{|c|c|c|c|c|c|c|}
\hline \multirow{3}{*}{$\begin{array}{c}\text { SOIL TREATMENT } \\
\text { ALL DOSAGES ADDED } \\
\text { TO } 15 \text { LBA. AIR DRIED } \\
\text { SOIL }\end{array}$} & \multirow{3}{*}{$\begin{array}{c}\text { Nituber of } \\
\text { Trees } \\
\text { Treated }\end{array}$} & \multirow{3}{*}{ SYMPTOMS } & \multicolumn{4}{|c|}{ AVERAGE MANGANESE CONTENT } \\
\hline & & & \multirow{2}{*}{$\begin{array}{c}\text { AT BEGINNING } \\
\text { OF THIS } \\
\text { EXPERIMENT } \\
\text { (BARK ONLY) } \\
\text { (pPM) }\end{array}$} & \multicolumn{2}{|c|}{$\begin{array}{l}\text { AT END OF THE } \\
\text { EXPERIMENT }\end{array}$} & \multirow{2}{*}{$\begin{array}{c}\text { SOIL PH } \\
\text { At } \\
\text { CONCLUSION } \\
\text { OF } \\
\text { EXPERIMIENT* }\end{array}$} \\
\hline & & & & $\begin{array}{l}\text { BARK } \\
(\mathrm{ppm})\end{array}$ & $\begin{array}{l}\text { LEAVES } \\
\text { (ppm) }\end{array}$ & \\
\hline $\mathrm{Ca}(\mathrm{OH})_{2}, \quad 6.8 \mathrm{gm} \ldots$ & 10 & NONE & 91 & 109 & 324 & 5.68 \\
\hline $\mathrm{Ca}(\mathrm{OH})_{2}, 13.6 \mathrm{gm} \ldots$ & 10 & NONE & so & 107 & 201 & 6.62 \\
\hline $\mathrm{CaCO}_{3}, 18.4 \mathrm{gm} \ldots$ & 8 & NONE & 一 & 74 & 424 & 6.71 \\
\hline $\mathrm{MgCO}_{3}, 16.7 \mathrm{gm} \quad \ldots$. & 5 & NONE & - & - & 236 & 6.25 \\
\hline $\mathrm{MgO}, 7.3 \mathrm{gm}$ & 5 & NONE & - & 一 & 539 & 6.44 \\
\hline $\mathrm{Na}_{2} \mathrm{CO}_{3}, 9.7 \mathrm{gm} \ldots$ & 10 & NONE & 92 & 139 & 272 & 7.50 \\
\hline Untreated controls & 16 & NONE & $87 t$ & 407 & 993 & 4.88 \\
\hline Intreated controls & 14 & MODERATE & 87 & 491 & 1244 & 4.88 \\
\hline
\end{tabular}

* Soil pH of one lot of soil tested at initiation of experiment was 4.80 .

$\div$ Average figures for both sets of checks in regard to average manganese content at the beginning of the experiment are based on all 30 checks taken together rather than being based on the lots of symptomatic and non-symptomatic controls considered separately, as is true also for the soil $\mathrm{pH}$ figures at the end of the experiment.

(13) found that plant absorption of manganese was decreased by the adclition of either calcium carbonate or dolomitic-limestone soil. Berger and Gerloff (6) worked on a potato disease known as "Stem Streak Necrosis" which is caused by too much manganese in the soil. This disease occurs only on highly acid soil. It has been observed at a $\mathrm{pH}$ of 4.7 , and has been much more serious at a still more acid reaction of $\mathrm{pH}$ 4.5. It was shown that Stem Streak Necrosis conld be prevented by giving the highly acid fields a light application of lime so as to bring about a less acid reaction of about $\mathrm{pH} 5.2$.

It is to be noted that 53.3 per cent of the control trees remained healthy and had a smaller amount of manganese in the leaves as compared with the control trees which developed the Internal Bark Necrosis. It is also to be noted that the pH values of the soil of the two check groups is the same throughout. It is evident that the difference in tolerance to manganese is not wholly a matter of $\mathrm{pH}$ but is clue to other factors. some of which may be inherent in the trees which were whips of the Delicious variety scions bucl-grafted onto Delicious or other scedling stocks.

(5) Treatment with $\mathrm{NaNO}_{3}$ seems to increase manganese uptak and increase Internal Bark Necrosis symptoms as well but does so with out lowering the $\mathrm{pH}$ of the treated soil as ( $\mathrm{NH})_{2} \mathrm{SO}_{4}$ does. 


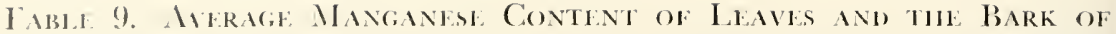

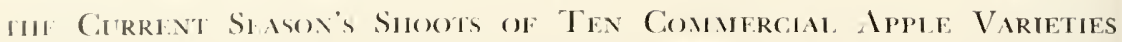

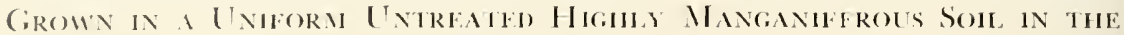
Granilouse.*

\begin{tabular}{|c|c|c|c|c|c|}
\hline \multirow{3}{*}{ VARIETT } & \multirow{3}{*}{$\begin{array}{c}\text { Number } \\
\text { of } \\
\text { Trees } \\
\text { Tested }\end{array}$} & \multicolumn{4}{|c|}{ MANGANESE CONTENT AT THE EXD OF THE EXPERINENT $†$} \\
\hline & & \multicolumn{2}{|c|}{ LEAVES } & \multicolumn{2}{|c|}{ BARK OF CURRENT SEASON SHOOTS } \\
\hline & & $\begin{array}{l}\text { RANGE } \\
(\mathrm{ppm})\end{array}$ & $\begin{array}{l}\text { A VERAGE } \\
(\mathrm{ppm})\end{array}$ & $\begin{array}{l}\text { RANGE } \\
(p p m)\end{array}$ & $\begin{array}{l}\text { AVERAGE } \\
(\mathrm{ppm})\end{array}$ \\
\hline Rome . & 23 & $199-1195$ & 558 & $105-495$ & 202 \\
\hline Stayman ........ & 5 & $659-915$ & 837 & $176-270$ & 228 \\
\hline Blaxstayman & 5 & $1280-3809$ & 2669 & $440-1108$ & $\$ 19$ \\
\hline Grimes ... & 5 & $401-689$ & 545 & $113-155$ & 135 \\
\hline Lodi $\ldots$ & 5 & $445-68 ?$ & 537 & $155-211$ & 182 \\
\hline \multicolumn{6}{|l|}{ Yellow } \\
\hline Transparent & 5 & $122-466$ & 149 & $135-16 t$ & 151 \\
\hline Turley & 5 & $360-472$ & 435 & $132-188$ & 163 \\
\hline \multicolumn{6}{|l|}{ Yellow } \\
\hline Delicious & 5 & $440-648$ & 516 & $126-205$ & 160 \\
\hline York $\ldots \ldots \ldots \ldots$ & 5 & $422-604$ & 544 & $255-413$ & 314 \\
\hline Delicious ... & 30 & $691-2068$ & 1110 & $272-798$ & 446 \\
\hline
\end{tabular}

* The soil $\mathrm{pH}$ was 4.80 at the beginning of the experiment.

$\dagger$ In regard to symptom production in relation to manganese uptake, it can be reported that among the five Blaxstaymen trees tested only the tree which took up the largest quantity of manganese (1108 ppm in the bark) showed slight symptoms of Internal Bark Necrosis. Of the 30 Delicious trees, 14 showed symptoms and had manganese contents of the bark ranging from 372 to $798 \mathrm{ppm}$. The 16 Delicious trees which showed no symptoms had a manganese content of the bark ranging from 272 to $535 \mathrm{ppm}$.

high rate of uptake and a low tolerance results in this commercial variety suffering the most from manganese toxicity. Low rates of manganesc absorption and a ligh level of tolerance nuy combine to make other varieties suffer less injury from manganese.

(7) A comparison of the ranges of manganese content found among healthy and diseased Delicions apple trees grown in a uniform soil withont treatment shows that the arerage manganese content for healthy trees was lower than that for diseased trees, but that the extremely high figures for manganese comlent of some healthy trees was higher than the extremely low figures shown by some diseased trees. The owerlapping of manganese-content ranges of healthy and diseased gromps was ronsiderable.

It will be noted, in the dita already presented, that individual trees show Huctuations of two sorts: (1) rather extreme variations in the manganese content of the leaves and bark, and (2) variations in tolerance to manganese as reflected in differences in the severity of the development of Internal Bark Necrosis. Table 10 shows the range of manganese intake by the varicty Delicious over a period of four years. The extremes lor leaves vary from $249 \mathrm{Ppm}$ manganese for healthy trees to 


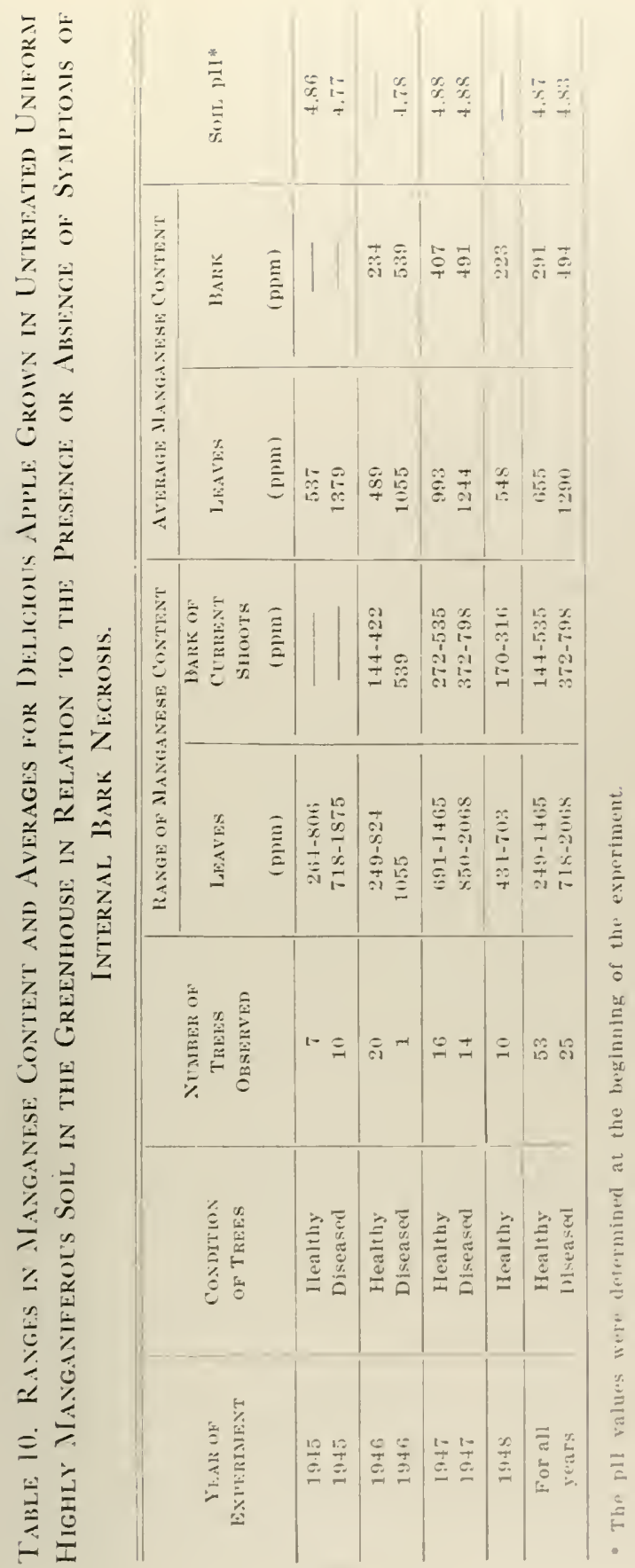


2068 ppon in diseased trecs. The maximum for leaves of the healthy trees averages higher (950) ppm) than the minimun for diseased tree: (87.t ppm). However, the arerage of the manganese content of leave from healthy trees was lower than that of leaves from diseased trees. The same is true of the manganese content of the bark.

It is evident from the variation in manganese content of individua trees receiving the sane treatmont that other factors in addition to the manganese content of leaves and bark are concerned with the develop ment of Internal Bark Necrosis. We can only suggest that two o these lactors are probably inherent, being existing differences anong trees in regard to their intake and tolerance of manganese.

(8) Minimum and arerage manganese content for leażes and bari of Delicious apple showing Intemal Bark Necrosis when grown in manganiferous soil treated with $\left(\mathrm{NH}_{4}\right)_{2} \mathrm{SO}_{4}$, Sulfur, and $\mathrm{H}_{2} \mathrm{SO}_{4}$ whici lower soil pH, and with $\mathrm{NaNO}_{3}$, which does not, were comparable. Thi indicates that $\mathrm{N}^{\mathrm{N}} \mathrm{N} \mathrm{O}_{3}$ stimulates the uptake of manganese in a differen manner than other compounds which appear to have this effect throug. their influence on soil acidity.

When a manganiferous soil is treated with chemicals which increas the acidity, the induction of Internal Bark Necrosis is rapidly increasec Increased manganese absorption also occurs when sodium nitrate i applied to such soils in which susceptible apple varieties are plantec Table 11 shows the lowest and the average quantities of manganese foun. in the leaves and bark of Delicious apple trees treated with chemical which induce Internal Bark Necrosis. It appears that the average Dr licious tree will develop Internal Bark Necrosis when the bark contain about 600 ppm of manganese, but some trees will tolerate considerabl more and some are less tolerant. Of special interest is the developmen of Internal Bark Necrosis in one tree containing 357 ppm manganese in

Table 11. The Loinest and the Arerage Manganese Contents a Which Ixternal Bark Necrosis was Produced ox Delicious Appl Growing in Solls Treated With $\left(\mathrm{NH}_{4}\right)_{2} \mathrm{SO}_{4}$, Sulfer, $\mathrm{H}_{2} \mathrm{SO}_{4}$ ANd $\mathrm{NaNO}$

\begin{tabular}{|c|c|c|c|c|c|}
\hline \multirow{3}{*}{ Soll Treatmext } & \multicolumn{4}{|c|}{ MAXGANESE CONTENT } & \multirow{3}{*}{$\begin{array}{c}\text { SOI, } \mathrm{pH} \\
\text { AT END OF } \\
\text { EXPERIMENT* } \\
(\mathrm{pH})\end{array}$} \\
\hline & \multicolumn{2}{|c|}{ LEAVES } & \multicolumn{2}{|c|}{ BARK OF CURREXT SHOOTS } & \\
\hline & $\begin{array}{l}\text { MIXTMEM } \\
\text { (ppm) }\end{array}$ & $\begin{array}{c}\text { AVERAGE } \\
-(\mathrm{ppm})\end{array}$ & $\begin{array}{c}\text { MINIMUM } \\
\text { (ppm) }\end{array}$ & $\begin{array}{c}\text { AVERAGE } \\
(\mathrm{ppm})\end{array}$ & \\
\hline$\left(\mathrm{NH}_{4}\right)_{2} \mathrm{SO}_{4}$ & 984 & 1367 & 425 & 608 & 4.60 \\
\hline Sulfur & 1069 & 1395 & 357 & 608 & 4.64 \\
\hline $\mathrm{H}_{21} \mathrm{SO}_{4}$ & 1861 & 2085 & 428 & 682 & 4.53 \\
\hline $\mathrm{Na}_{\mathrm{NO}}$ & 1113 & 2095 & 498 & 609 & 4.90 \\
\hline
\end{tabular}

* Soil pH was 4.80 at the beginning of the experiment. 
the batk. This is the lowest amount found in the birk of hundreds of affected trees which have been analyzed for manganese content.

The soil treatment with sodium nitrate, a common source of nitrogen used in orchards and on many other crops, produced unexpected results. Its use tended to increase both $\mathrm{pH}$ and the production of Internal Bark Necrosis. These results are seemingly contradictory because an increase of the soil $\mathrm{pH}$ usually tends to decrease the solubility of manganese and so to reduce the likelihood that Internal Bark Necrosis will develop. Funchess (15) in the Alabana Agricultural Experinent Station found that manganese toxicity developed in sereral crops grown on soils high in nitrates but did not appear in plots of low nitrate concent. Friedricksen (12) found the manganese content of leaves was less in cultures supplied with ammonia as a source of nitrogen than in cultures containing nitrates as the nitrogen source. Sidiris, Young and Krauss (29) showed experimentally that the change of $\mathrm{pH}$ during at (woreek interval between renewal of the nutrient solutions was from $6.6 \mathrm{to}$ 1.t for ammonia nitrogen and from 4.4 to 6.8 for nitratte nitrogen. Sidiris and Young (28) later found that the concentration of both manganese und iron increased in plant tissues in proportion to the amounts of nitrate nitrogen in the nutrient solution. Our results with sodium nitrate uppear to substantiate the findings of these investigators.

(9) Variations exist between the manganese contents of different urts of the same tree as well as between indiridual I)elicions trees and mong different commercial rarieties tested.

Sometimes the symptoms of Internal Bark Necrosis are rather unimmly distributed on the main stem and branches but they may be sund to be more pronounced on or confined to one side of the trunk nd to one or more of the branches. This uneren symptom distribution as considered to be associated with variable soil conditions surromeling re roots and perhaps also due to a difference between the alosorptive upacity of different roots. In the greenhouse experinucnts carried out in niform soils, the irregular distribution of the symptoms is not enpecially parent, yet on careful inspection certain twigs of the young ares show riation in the mumber and distribution of the necrotic ancas in the uk. The twigs of each of two trees in the 1916 experiment. growing 1 soil treated with 2.8 gin sulfurir acid per 15 llo soil, Were analy/ed paratcly with resules shown in Table le. In Trec 72, with symptoms milorm moderate severity, the manganese content of the hall bitrical rectly with the extent to which symptoms were shown bs the indivial twigs. In the case of Tree $7 \cdot 1$ the bark of visibls allected twign wam und to contain more mangance than the batk of twigh howing litule on

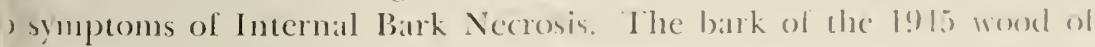




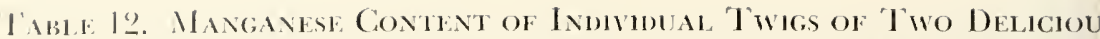
IPPLe Tries Grown in the Greenhouse in Highly Manganiferou Soll. TREATHD WTH $\mathrm{H}_{2} \mathrm{SO}_{4}$ iN 1946.

\begin{tabular}{|c|c|c|c|c|c|}
\hline \multirow[b]{2}{*}{$\begin{array}{c}\text { TrEk } \\
\text { NuMBER }\end{array}$} & \multirow[b]{2}{*}{$\begin{array}{c}\text { TWIG } \\
\text { NuMber }\end{array}$} & \multirow[b]{2}{*}{$\begin{array}{l}\text { SYMPTOM } \\
\text { SEVERITY }\end{array}$} & \multirow[b]{2}{*}{$\begin{array}{c}\text { Percentage of } \\
\text { TWig Length } \\
\text { Visably AFFECted }\end{array}$} & \multicolumn{2}{|c|}{ Manganese Content } \\
\hline & & & & $\begin{array}{l}\text { LEAVES } \\
(\mathrm{ppm})\end{array}$ & $\begin{array}{c}\text { BARK OF } 1946 \\
\text { SHOOT GROWTK } \\
\text { (ppm) }\end{array}$ \\
\hline 72 & $\begin{array}{l}1 \\
2 \\
3\end{array}$ & $\begin{array}{l}\text { Moderate } \\
\text { Moderate } \\
\text { Moderate }\end{array}$ & $\begin{array}{r}43 \\
79 \\
100\end{array}$ & $\begin{array}{l}1793 \\
1934 \\
1858\end{array}$ & $\begin{array}{l}390 \\
442 \\
498\end{array}$ \\
\hline 74 & $\begin{array}{l}1 \\
2 \\
3 \\
4 \\
5\end{array}$ & $\begin{array}{c}\text { Moderate } \\
\text { Moderate } \\
\text { Slight } \\
\text { Trace } \\
\text { None }\end{array}$ & $\begin{array}{l}70 \\
25 \\
- \\
-\end{array}$ & $\begin{array}{c}2473 \\
2168 \\
-* \\
- \\
-\end{array}$ & $\begin{array}{l}615 \\
621 \\
651 \\
453 \\
468\end{array}$ \\
\hline
\end{tabular}

* Alerage manganese coutent for leaves of twigs 3, 4, and 5 taken together was 22 : ppm.

Tree 74 contained on the average 654 ppm manganese and the root ban 674 ppm manganese. The average manganese content for the 1945 bat of Tree 72 was 454 ppm and the root bark averaged 516 ppm manganes In both cases, the root bark contained more manganese than the ste bark even though necrotic lesions have never been noted in roots , diseased trees. ${ }^{5}$ The soil had a $\mathrm{pH}$ of 4.78 at the end of the experimen

(10) The exchangeable and readily reducible manganese content six West Virginia orchard soils, taken in most cases from beneath bot naturally diseased and healthy trees, showed in all cases manganese qual tities ample for normal growth and in most cases sufficient to induc Internal Bark Necrosis, provided that the soils were made sufficient acid to make the manganese arailable in toxic concentrations.

The nunganese content of several orchard soils was determined $b$ the method described by Sherman, McHargue and Hodgkiss (27). Tl soil samples were brought to the laboratory, air clried, pulverized, scree el through a 20-mesh sieve, and stored in air-tight glass containers unt they could be analyzed. No attempt was made to determine separate the water-soluble manganese since it is assumed that the very sma anount of this form present would be included in the exchangeab manganese.

From the Huxham orchard near Huntington, in which Intern: Bark Necrosis was frequently observed, soil samples were taken at in tervals over a period of one year from one small plot in the open when young trees showing severe Internal Bark Necrosis had been remover

The nature and origin of the rootstock are unknown. 
This repeated sampling from the same place made it possible to detcrnmine the degree of variation in exchangeable manganese which might be net with at different seasons within the same soil. There was considerable unilormity except for the two samples taken in July and September of the same year which were comparatively high in exchangeable mangancse. Temperature and moisture variations could be responsible for this difference. Fujimoto and Sherman $(13,14)$ studied the effects of drying, heating, and wetting on the level of exchangeable manganese in Hawaiian soils and found that both drying and heating increased the exchangeable manganese, while wetting decreased it. Such changes in climatic conditions may be responsible for the erratic occurrence of Internal Bark Necrosis noted in the field, where the disease is much more scrious in some seasons than in others when it may not appear at all. Hot, dry seasons would tend to favor the appearance of Internal Bark Nerosis, while cool, wet seasons would retard its development.

The variation is considerable in both exchangeable and reducible manganese in the five other orchards as is shown in Table 1.3 but not more so than would be expected from different soil types.

(11) A uniform highly manganiferous soil was subdivided for trealments with acidifying and neutralizing chernicals and with sodinm nitrute 11) learn the effect of these treatments on the incidence and severity of Internal Bark Necrosis on trees grown in the treated soils (comparr Tables 4-8) and upon quantities of exchangeable and easily reducible manganese to be found in the soils after treatment.

All the soil was collected from orchard No. 1 in two different years.": IIl samples marked X were collected in 19.16 and those marked A in 947. As is shown in Table 14 all treatments involving acidilication of he soil caused an increase in Internal Bark Necrosis. All neutralizing reatments produced healthy trees and a relatively high $\mathrm{pH}$. The two heck soils with $\mathrm{pH}$ comparatively low happened, in this experinent. (o) roduce healthy trees only, but it is known from a complete study of 30 uch check trees (Table 3) that 46.7 percent of this larger sample of heck trees became discased. This dilference in response is believed to e due to inherent differences in individual trees growing under unitorm mditions. The response to treatment with sodium nitrate, which inuced a pH near the border line and a low exchangeable manganese, lises questions which cammot now be satisfactorily answered (sece discuson of data presented in Table 10, Page 19). An intricate relation of itrates to the intake of manganese in abundance at a companativels igh $\mathrm{pH}$ contrasts with the simpler effect of the application of ammonium

- The Huxham orchard near Huntington ln which Internal llark dor rosis wats freyuent observed. 


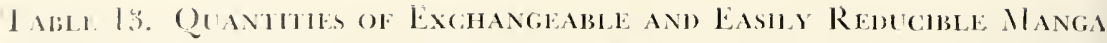

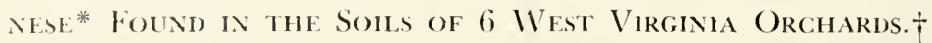

\begin{tabular}{|c|c|c|c|c|c|}
\hline \multirow[b]{2}{*}{$\begin{array}{l}\text { Orchard } \\
\text { Number }\end{array}$} & \multirow[b]{2}{*}{$\begin{array}{l}\text { SAMPLING } \\
\text { DATE }\end{array}$} & \multirow{2}{*}{$\begin{array}{l}\text { SOURCE OF } \\
\text { SOIL SAMPLE }\end{array}$} & \multirow[b]{2}{*}{$\begin{array}{l}\text { Soli } \\
\mathrm{pH}\end{array}$} & \multicolumn{2}{|c|}{ MANGANESE } \\
\hline & & & & EXCHANGEABLE & $\begin{array}{c}\text { EASILY } \\
\text { REDUCIBLE }\end{array}$ \\
\hline 1 & $\begin{array}{l}\text { June } 9 \\
\text { July } 7 \\
\text { July } 28 \\
\text { August } 9 \\
\text { September } 11 \\
\text { April } 25 \\
\text { May } 21 \\
\text { July } 23\end{array}$ & $\begin{array}{l}\text { Abandoned site** } \\
\text { Abandoned site } \\
\text { Abandoned site } \\
\text { Abandoned site } \\
\text { Abandoned site } \\
\text { Abaudoned site } \\
\text { Abandoned site } \\
\text { Abandoned site }\end{array}$ & $\begin{array}{l}5.19 \\
5.52 \\
5.33 \\
5.49 \\
5.33 \\
5.31 \\
5.28 \\
\end{array}$ & $\begin{array}{r}\text { (ppm) } \\
63.7 \\
138.0 \\
51.4 \\
58.5 \\
104.1 \\
86.5 \\
83.0 \\
85.4\end{array}$ & $\begin{array}{l}(\mathrm{ppm}) \\
416.5 \\
313.5 \\
258.5 \\
446.7 \\
404.8 \\
363.2 \\
478.8 \\
470.3\end{array}$ \\
\hline 2 & $\begin{array}{l}\text { October } 2 \\
\text { October } 2 \\
\text { October } 2 \\
\text { September } 2 \\
\text { September } 2\end{array}$ & 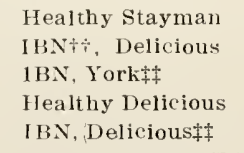 & $\begin{array}{l}4.26 \\
4.84 \\
6.50 \\
5.83 \\
6.40\end{array}$ & $\begin{array}{r}12.2 \\
5.9 \\
4.1 \\
50.3 \\
16.1\end{array}$ & $\begin{array}{r}135.4 \\
17.6 \\
20.8 \\
112.9 \\
231.6\end{array}$ \\
\hline 3 & $\begin{array}{l}\text { June } 27 \\
\text { June } 27 \\
\text { August } 14 \\
\text { August } 14 \\
\text { August } 17\end{array}$ & $\begin{array}{l}\text { Healthy Deliclous } \\
\text { IBN, Delicious } \\
\text { Healthy Delicious } \\
\text { IBN, Delicious } \\
\text { IBN, Delicious }\end{array}$ & $\begin{array}{l}4.41 \\
4.33 \\
4.50 \\
4.46 \\
4.38\end{array}$ & $\begin{array}{r}67.8 \\
73.7 \\
80.0 \\
17.8 \\
164.0\end{array}$ & $\begin{array}{r}222.2 \\
134.0 \\
304.7 \\
11.6 \\
143.6\end{array}$ \\
\hline 4 & $\begin{array}{l}\text { June } 5 \\
\text { June } 5\end{array}$ & $\begin{array}{l}\text { IBN, Delicious } \\
\text { Healthy Delicious }\end{array}$ & $\begin{array}{l}4.90 \\
4.60\end{array}$ & $\begin{array}{l}41.6 \\
15.7\end{array}$ & $\begin{array}{l}240.2 \\
161.2\end{array}$ \\
\hline 5 & $\begin{array}{l}\text { October } 21 \\
\text { October } 21 \\
\text { September } 2\end{array}$ & $\begin{array}{l}\text { IBN, Delicious } \\
\text { Orchard entrance } \\
\text { IBN, Delicious }\end{array}$ & $\frac{4.78}{4.43}$ & $\begin{array}{l}19.4 \\
11.2 \\
76.6\end{array}$ & $\begin{array}{r}217.6 \\
80.7 \\
345.7\end{array}$ \\
\hline 6 & $\begin{array}{l}\text { September } 29 \\
\text { September } 29\end{array}$ & $\begin{array}{l}\text { Tree with bitter pit } \\
\text { Tree with bitter pit }\end{array}$ & 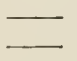 & $\begin{array}{l}69.0 \\
13.2\end{array}$ & $\begin{array}{r}254.4 \\
3.9\end{array}$ \\
\hline
\end{tabular}

* As determined by the method of Sherman, McHargue and Hodgkiss (27).

* Orchard 1 was the Huxham orchard near Huntington in Cabell County. Orchards and 3 were situated in Hampshire and Monongalia Counties, respectively. The Iocatio of Orchard 4 is now uncertain. Orchards 5 and 6 were situated in Morgan and Maso Counties, respectively.

+ The sampling period extended from June, 1946 to September, 1947 .

** All samples from this orchard taken at different seasons from the same site whic was previously abandoned because of severity of the development of Internal Bark Necrosi ill young trees growing there.

$+\dagger 1 \mathrm{BN}=$ Internal Bark Necrosis.

䗇 It is uncertain if soll around this diseased tree was given a neutralizing treatmer after symptoms appeared and before sampling.

sullate which lowers the $\mathrm{pH}$ and in so doing promotes the intake e llatigatlese.

It is mofortunate that the soluble manganese content of the soil was not detemined. Presumably, the manganese in the soil solutio would have been more readily available to the trees than the other forn of manganese. It may be noted that soil treated with sulfur, sulfur acid, and manganese sulfate contained greater concentrations of ex changeable manganese than the control soil. All of the trees growing $\mathrm{i}$ 


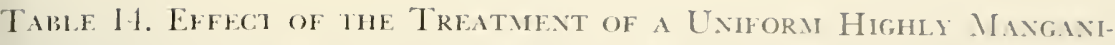

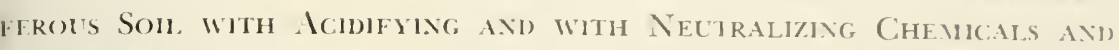

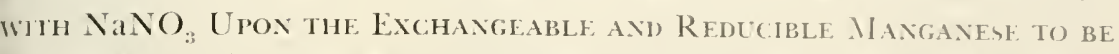

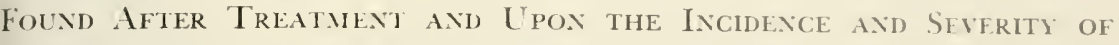
INTERNAL Bark Necrosis.*

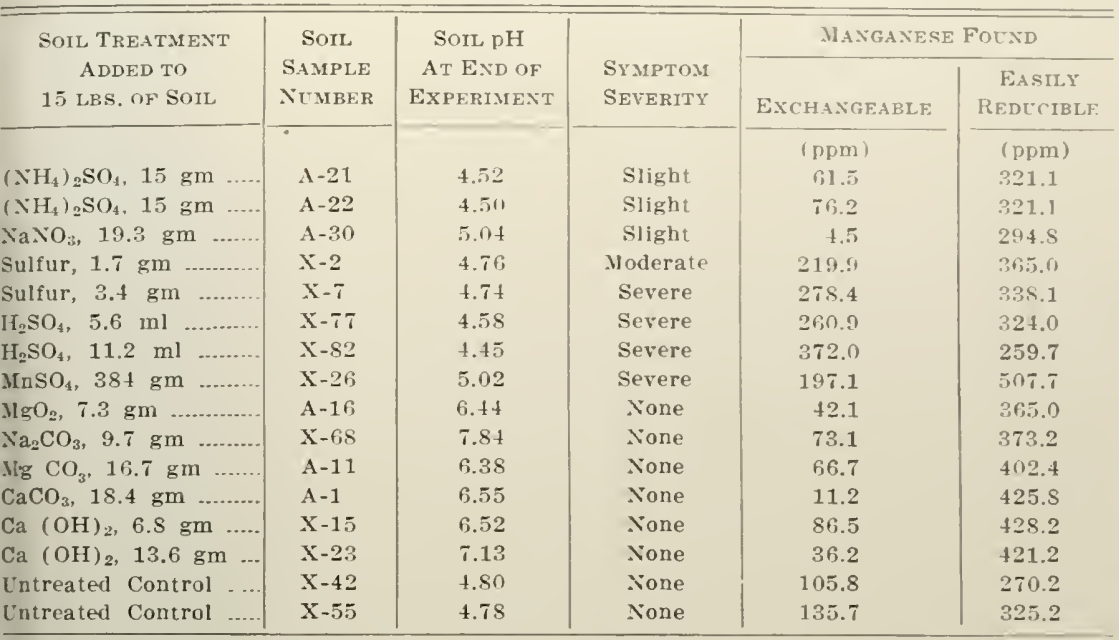

* All soil was collected from Orchard 1 in two different years. All X - numbererl samples were collected in 1946 and $\mathrm{A}$ - numbered samples in 1947 .

,oils receiving these treatments were moderately to severely discased. The oncentration of exchanceable manganese in soils treated with alkalizing igents was less than that of the control soils. None of these trees exribited symptoms of Internal Bark Necrosis. Soils treated with annonium sulfate and sodium nitrate contained less exchangeable mangarese than the control soils. The trees which grew in the soils treated vith either ammonium sulfate or sodium nitrate exhibited slight symp)mus of Internal Bark Necrosis, while the trees which grew in the control sils did not. The one certain conclusion which can now be reached, II the basis of the available evidence, is that the symptoms of Intcrial batk Necrosis did not appear in trees grown in soils to which lime on ther alkalizing agents were adked.

\section{iummary}

NTERNAL, Bark Necrosis is a Hon-parasitic discase atferting the apple tree. It is of primary importance on the varicty I)elicious and its sports, although other varieties may be alfected.

In the early stages of the liscase small elevations are visible on the jidemis and young bark which, if cut open, reveal dead arean within 
the cortex and imner bak which oftentimes extend into the rood. As the disease develops, the older bark becomes rough and scaly, the affected limbs wnthrifty, and death frequently follows.

The disease occurs when susceptible trees, under some conditions, take up manganese from the soil in such quantities that the tissues become poisoned as it accummlates within them. Manganese toxicity resulting in luternal Bark Necrosis develops most commonly on trees growing in soils of high manganese content and which are also usually highly acid.

Manganese is a minos elcnent essential in minute quantities for plant growth. It is insoluble in neutral or alkaline soils, but becomes. progressively more soluble as the soil acidity increases beyond the 6.5 pH level. Intemal Bark Nocrosis never developed on apple under experinental conditions when the soil pH was above 5.3. It is recommended that orchardists mantain the soil pH at or above 5.5 to prevent development of this disease. Consideration should be given to the fact that treatments which acidify the soil tend to increase the quantity of available manganesc. The application of sodim nitrate ras foumd also to favor development of the discase without causing any increase in soil acidity such as resulted from the addition of ammonium sulfate. This should be considered before recommending the application of sodium nitrate as a lertilizer to manganiferous soils planted to the variety Delicious. The application of lime and other neutralizing sub stances reduces the availability of manganese. The inciclence and sever ity of lnternal Bark Necrosis usually can be controlled by such soil neutralizing treatments.

\section{Literature Cited}

I. Arnon, D. I., “Ammonium and Nitrate Nitrogen Nutrition of Barley at Different Seasons in Relation to Hydrogen-ion Concentration Manganese, Copper, and Oxygen Supply." Soil Sci., 44:91-122 (1937)

2. Berg, Anthony, "Black Pox" and Other Apple-Bark Diseases Com. momly Known as Mensles. WV. Va. Univ. Agr. Exp. Sta. Bul. 260:1-31 Fig. 1-3, Pl 1-7 (1934).

9. Berg, Anthony, and Clulo, Genevicve, "Boron in Relation to In ternal Bark Necrosis of Apple." (Abs.) Phytopathology, 33:1 (1943)

4. Berg, Anthony, and Clülo, Genevieve, "Manganese Toxicity, a Factos of Internal Bark Necrosis (Apple Measles)." (Abs.) Phytopathology $36: 395$ (1946).

5. Berg, Anthony, and Clulo, Genevieve, "The Relation of Manganest to Internal Bark Necrosis of Apple." Science, 104:265-266 (1946) 
6. Berger, K. C., and Crerloff, G. C., "Manganese Toxicity in Potatoes in Relation to Strong Soil Acidity:" Proceedings, Soil Sci. Soc. Amer., I2:310-14 (1948).

7. Clulo, Genevieve, "The Production of Internal Bark Necrosis of Apple in Sand and Soil Cultures." (Abs.) Phytopathology', 39:502 (1949).

8. Clulo, Genevieve, "Pathological Anatomy of Internal Bark Necrosis of Apple." (Alos.) Phytopathology), 40:5 (1950).

9. Clulo, Genevieve, and Berg, Anthony, "Distribution of Boron in the Tissues of the Apple Tree." Procesdings, Ir'. I'a. Acad. Sci, 19:43-49 (1949).

(1). Crawford, R. F., Apple Measles. New Mexico Agr. Exp. Sta. Bul. 25I:1-15 (1937).

1. Duegan, J. C., and Isely, Dwight, "Leafhopper Oviposition, the Cause of One Form of Apple Measles." Phytopathology", 35:87()-876. Fig. $1-2$ (1945).

2. Friedricsen, Ingeberg, "Function of Manganese in the Assimilation of Food By Higher Plants." Planta, 34:67-87 (1944); Chem. Alis.. 43:1836 g. (1949).

3. Fujimoto, Chas. K., and Sherman, G. Donald, "The Effect of Drying, Heating, and Wetting on the Level of Exchangeable Manganese in Hawaiian Soils." Proceedings, Soil Sci. Soc. Am., 10:107-112 (1945).

I. Fujimoto, Chas. K., and Sherman, G. Donald, "Behavior of Manganese in the Soil and the Manganese Cycle." Sorl Sci., 66:131-45 (1948).

- Funchess, M. J., The Dezuelopment of Soluble Manganese in Acid Soils as Influenced by Certain Nitrogenous Fertilizers. Ala. Agr. Exp. Sta. Bul. 201:37-38 (1918).

Gutschick, F., "Research on the Manganese and Iron Cycles in the Forest." Tharandt. Jahrb.. 91:595-(645 (1910): (Alss.) Soils \& Fert., X p. 362 (1954); For. Abs., 8(350)G. (1946).

Hewitt, J. L., and Truax, H. E., An L'nknown Apple Tree Disease. Ark. Agr. Exp. Sta. Bul. 112:481-491, Figs. 1-13 (1912).

Hildebrand, E. M., "Intemal Bark Necrosis of 1) licious Apple, :: Physiogenic 'Boron-cleficiency' Disease." (Abs.) Phytopatholngl. 29: 10 (1939).

Hopkins, C. J., An Apple Disease Occurring in the Elgin Distrit. Union South Arica Dept. Agr. Sci. Bul. 61:1-17. I'l. I, Fig. I (I!) Lacy, Margaret S., and Dowson, Walter J., "A Batclerial Canker of Apple Trees." Amm. Appl. Biol., 18:30-36, Pl. I, Tig. 3 (1!31).

Orton, C. R., and Clulo, Cencrieve, "Manngancese (ontent of Apple Trees." (Abs.) Phylopathology, I(1:21 (1950). 
22. Rhoads, Arthur S., "Apple Measles, With Special Reference to the Comparative Susceptibility and Resistance of Apple Varieties to the Disease in Missouri." Phytopathology, 14:289-314, Fig. 1, Pl. XVII XXI (192-1).

29. Roberts, John W., "Target 'Canker' of Apples and Pears." Phyto pathology, 17:735-738 (1927).

24. Roberts, John W., "Apple Target Canker, Measles and Rough Bark. Phytopathology, 17:735-738 (1934).

25. Rose, D. H., "Blister Spot of Apples and its Relation to a Diseas of Apple Bark." Phytopathology, 7:198-208 (1917).

26. Shannon, L. M., "Internal Bark Necrosis of the Delicious Apple." Amer. Soc. Hort. Sci. Proceedings, 64:165-174 (1954).

27. Sherman, G. D., McHargue, J. S., and Hodgkiss, W. S., "Determina tion of Active Manganese in Soil." Soil Sci.. 54:253-257 (1942).

28. Sideris, C. P., and Young, H. G., "Growth and Chemical Compos tion of Anamas comosus in Solution Cultures with Different Iron Manganese Ratios." Plant Plysiology', 24:416-440 (1949).

29. Sideris, C.P., Young, H. Y., and Krauss, B. H., "Effects of Iron o the Growth and Ash Constituents of Ananas comosus." Plant Ph: siology, 18:608-6932 (1943).

80. Willard, H. H., and Greathouse, L. H., "Colorimetric Deteminatio of Manganese by Oxidation with Periodate." Jour. Amer. Chen Soc., 39:2366-2377 (1917).

31. Young, H. C., and Winter, H. F., "The Effect of Boron, Manganes and Zinc on the Control of Apple Measles." Ohio Agr. Exp. St Bimonth. Bull. XXII, No. 188, 147-152 (1937). 